\title{
Utilization of Golden Apple Snail (Pomacea canaliculata) Shells as Liming Materials for Pangasius sp Culture in Swamp Fish Pond
}

\author{
Dade Jubaedah ${ }^{1,}{ }^{*}$, Marini Wijayanti ${ }^{1}$, Marsi $^{2}$, and Nazario Rizaldy ${ }^{1}$ \\ ${ }^{1}$ Aquaculture Study Program, Agriculture Faculty, Universitas Sriwijaya \\ ${ }^{2}$ Soil Science Department, Agriculture Faculty, Universitas Sriwijaya
}

\begin{abstract}
Liming ponds is intended to increase swamp soil and water fish ponds $\mathrm{pH}$. The golden apple snail (Pomacea canalicuata) is one kinds of agriculture pest which is potentially used as material of lime. The golden apple snail shells containing $\mathrm{CaO}(91.62 \%)$ and $\mathrm{MgO}(1.66 \%)$. This study aims to determine the best dosage of lime derived from golden apple snail shells to increase the $\mathrm{pH}$ of soil and water, as well as the survival and growth rate of catfish fingerlings. This study used Completely Randomized Design (CRD) with 5 treatments (4 treatments of different dosage of lime derived from golden apple snails and 1 treatment using calcite and 3 replications. The treatments used consisted of different dosages of lime : P1) 4 ton/ha; P2) 5 ton/ha; P3) 6 ton/ha; P4) 7 ton/ha and P5) calcite 6 ton/ha equivalent to $\mathrm{CaO}$. The result showed that maximal $\mathrm{pH}$ value of $\mathrm{P} 4$ (lime derived from $P$. canaliculata 7 ton/ha) is almost same as $\mathrm{pH}$ of P5 (calcite 6 ton/ha) but P4 is faster to reach than that of P5. At the final day of research $\mathrm{P} 4$ has no significant different with calcite 6 ton/ha (P5) for alkalinity, fish growth and feed efficiency.
\end{abstract}

\section{Introduction}

The soil's $\mathrm{pH}$ of swamps is generally less than 5.9 [1] and water $\mathrm{pH}$ of swamps below 4 [2]. The downstream of swamp has $\mathrm{pH}$ value of water ranged from 4.7 to 5.6 [3]. Low soil and water $\mathrm{pH}$ retarted growth and reproduction eventually caused mortality of fish. [4].

Liming of ponds is intended to increase soil and water fish ponds $\mathrm{pH}$ value. Calcite and dolomite are widely used by farmers to increase soil and water $\mathrm{pH}$. However, these limes are derived from natural and unrewenable lime mineral materials. Therefore it is a need to find an alternatve rewenable, domistic waste, or by-product material that can used as lime materials. Anadara granosa shells as an alternative liming materials is proven to increase soils and water's pH swamp catfish ponds [2]. Pomacea canaliculata (golden apple snail) is one of agricultural pest that the shells are potential to use as liming materials. The golden apple snail shell contain $91.62 \% \mathrm{CaO}$ and $1.66 \% \mathrm{MgO}$. The aims of this research were to

\footnotetext{
*Corresponding author: dadejubaedah@fp.unsri.ac.id
} 
evaluate the potency of lime derived from $P$. canaliculata shells to raise soil and water $\mathrm{pH}$ of swamp fish ponds and to evaluate its effect to survival and growth of Pangasius $s p$.

\section{Materials and Methods}

The study was conducted from January to March 2018 at Field Experimental Station, Aquaculture Study Program, Faculty of Agriculture, Univesitas Sriwijaya, South Sumatera Province, Indonesia.

\subsection{Preparing Lime Materials and Liming}

P.canaliculata shells was activated by burning using furnace at temperature of $800^{\circ} \mathrm{C}$ for an hour, then mashed and sieved with 60, 40 and 20 mesh-size sieves in order to get lime with $50 \%$ passed 60 mesh-size sieve, $25 \%$ passed 40 mesh-sized sieve, and $25 \%$ passed 20 mesh-size sieve. Five liming treatments were investigated, namely: P1) 4 ton/ha; P2) 5 ton/ha; P3) 6 ton/ha; P4) 7 ton/ha and P5) calcite 6 ton/ha of lime equivalent to $\mathrm{CaO}$. Lime derived from P.canaliculata shells and calcite were applied homogeneously on soil ponds and incubated for 7 days at field capacity soil moisture. Water was filled to the ponds and and let equilibrated for 3 days. Fish stocked on ponds and cultured for 60 days.

\subsection{Fish Culture}

Fiveteens fish ponds filled with $7.500 \mathrm{~L}$ swamp water at 7 days after liming. The three hundreds of $5 \pm 0.5 \mathrm{~cm}$ length Pangasius $s p$ were acclimatized in swamp water for one week before being used in the study. Then, every pond was stocked with 15 fish at 10 days after liming. The fish were fed to satiation three times per day with an artificial diet containing $40 \%$ protein. For 60 days of cultured period (starting at 10 days after liming), water samples were collected and analyzed, as well as growth of fish was measured every 20 days.

\subsection{Experimental Variables and Analytical Procedurs}

Water quality, survival and growth performance variables were observed in the present work. The water's $\mathrm{pH}$, total alkalinity, and total ammonia were monitored every 20 day in all pond. Besides, water temperature and $\mathrm{pH}$ were recorded daily. The water $\mathrm{pH}$ was measured by using a portable $\mathrm{pH}$ meter. The water temperature was observed by using a digital handy thermometer. The analytical determinations of total alkalinity and total ammonia were carried out according to the guidelines presented by APHA [5]. The fish final body weight and length, survival and feed efficiency were observed in all experimental units.

Water quality, survival and growth performance results were statistically analyzed according to the two-way Anova to detect if there was any significant influence due to experimental treatments. When the influence was at least significant, the means were compared using Dunnet test with P5 as control for P1, P2, P3 and P4. The 5\% significance level was adopted in all statistical analysis. 


\subsection{Data Analysis}

The fish survival rate was calculated from the initial number of fish and mortality after the experiment was completed. The absolute growth of fish were determined from the mean of initial and final weight and length of fish, respectively for absolute weight growth and length growth. Meanwhile, feed efficiency was calculated by the formula as follows:

$$
\mathrm{FE}=\{(\mathrm{wt}+\mathrm{D})-\mathrm{wo}) / \mathrm{F})\} \times 100 \%
$$

$$
\text { Where: } \begin{aligned}
\mathrm{FE} & =\text { feed efficiency } \\
\mathrm{Wt} & =\text { total final fish weight } \\
\mathrm{Wo} & =\text { total initial fish weight } \\
\mathrm{D} & =\text { weight of dead fish } \\
\mathrm{F} & =\text { total feed consumption }
\end{aligned}
$$

\section{Results and Discussions}

The initial Soil $\mathrm{pH}$ used in this current study was 3.66 and then soil $\mathrm{pH}$ increased due to liming to $\mathrm{pH}$ 7.01-7.63 after incubated for 7 days. Regression etween incubation time and $\mathrm{pH}$ of soil showed polynomial quadratic patern (Figure 1). Regression between days of culture and $\mathrm{pH}$ of soils showed polynomial quadratic patterns for all dosages of lime including calcite (Figure 2). It is showed that application of lime materials derived from P.canaliculata shell positively influenced $\mathrm{pH}$ of soils. The higher dosage of lime resulted the higher soil $\mathrm{pH}$. Lime derived from P.canaliculata shells contained $91.62 \% \mathrm{CaO}$ and $21.65 \% \mathrm{MgO}$. Reaction between $\mathrm{CaO}$ or $\mathrm{MgO}$ and $\mathrm{H}_{2} \mathrm{O}$ produced $\mathrm{Ca}(\mathrm{OH})_{2}$ or $\mathrm{Mg}(\mathrm{OH})_{2}$ and eventually increased soil or water $\mathrm{pH}$.

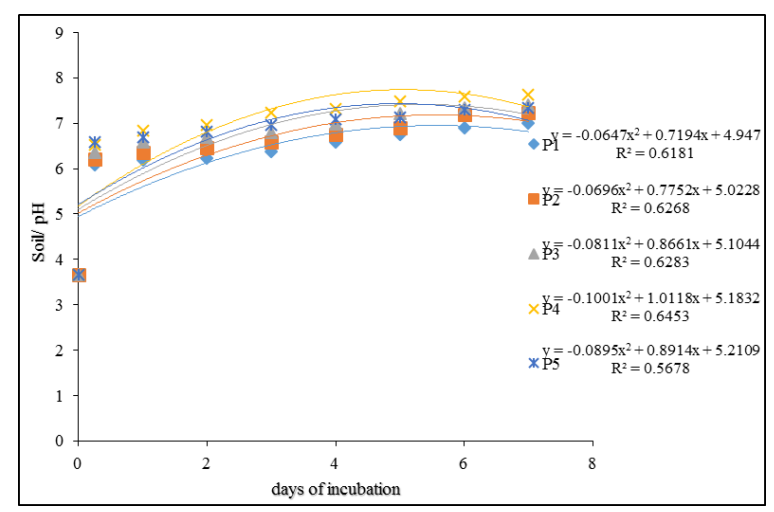

Fig. 1. Relationship between days of incubation with soils $\mathrm{pH}$

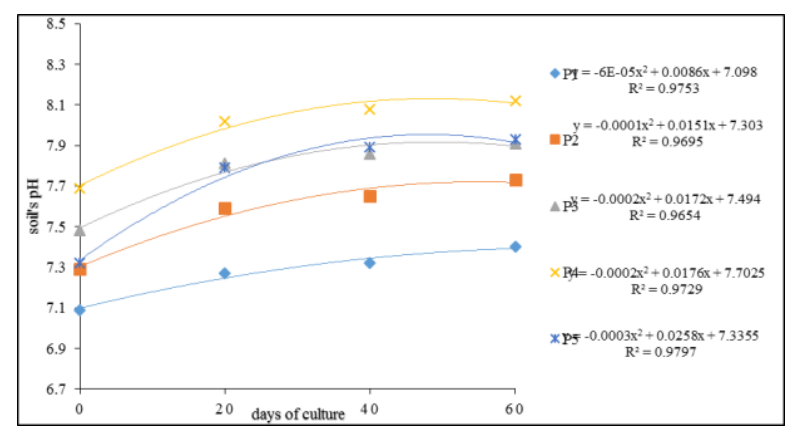


Fig. 2. Relationship between days of culture and soil's $\mathrm{pH}$

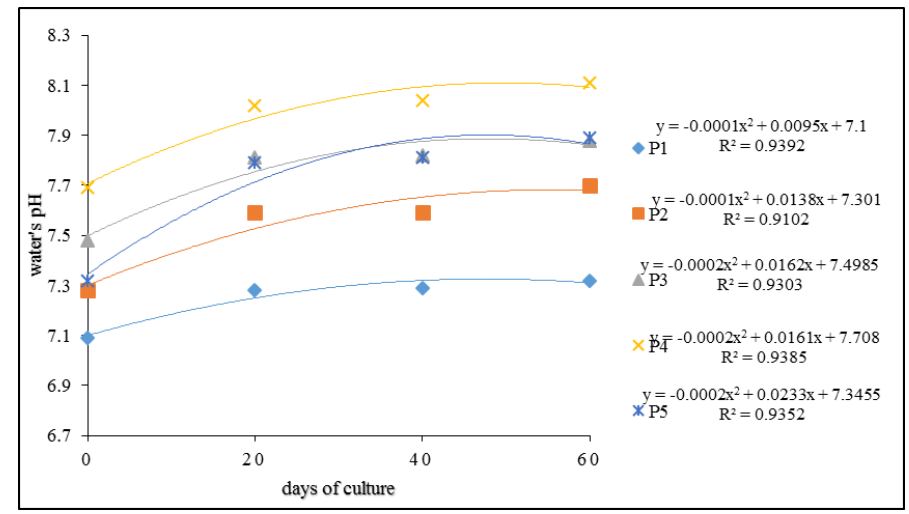

Fig. 3. Relationship between days of culture and water's $\mathrm{pH}$

The initial water $\mathrm{pH}$ used in this research was 3.9, then water $\mathrm{pH}$ increased following polynomial quadratic patterns for 60 days of fish culture due to lime application (Figure 3). According to equations shown in Fig. 3, the maximum $\mathrm{pH}$ and days after lime application to reach maximum water $\mathrm{pH}$ can be calculated. The maximum water $\mathrm{pH}$ and when it is were 7.33 at 48 days after liming, 7.78 at 69 days after liming, 7.83 at 41 days after liming, 8.03 at 40 days after liming and 8.02 at 58 days after liming, respectively for P1, P2, P3, P4 and $\mathrm{P} 5$. The highest maximum water $\mathrm{pH}$ among treatments was observed on $\mathrm{P} 4$ ( 7 ton/ha lime derived from $P$. canaliculata shells) with maximum $\mathrm{pH}$ value 8.03 at day 40 . Meanwhile calcite 6 ton/ha can reach almost same maximal $\mathrm{pH}$ value (8.02) but has longer time (58 days after liming) than lime derived from $P$. canaliculata dosage 7 ton $/$ ha. Furthermore, based on the equations (Figure 3) and minimum water $\mathrm{pH}(6.5)$ for optimal growth of Pangasius $s p$, the next lime application should be considered after day, $128^{\text {th }}$ and $144^{\text {th }}$ for P4 and P5, respectively.

The water alkalinity increased with increasing of dosage of lime (Figure 4). Liming materials are used widely in aquaculture mainly to neutralize acidity in pond soil and water, to increase alkalinity and hardness of water, and to destroy disease carriers in soil [6]. According to Dunnet test (Table 1 ) showed that at day- 0 of culture, the alkalinity of water of P2 (liming with 5 ton/ha lime derived from $P$. canaliculata) has no significant different with calcite 6 ton/ha (P5), but at day-20,40 and 60, the alkalinity of water of P3 (liming with 6 ton/ha lime derived from $P$. canaliculata) has no significant effect with calcite (P5). P4 ( liming with 7 ton/ha lime derived from $P$. canaliculata) has highest alkalinity and significat difference from alkalnity of pond treated with calcite 6 ton/ha.

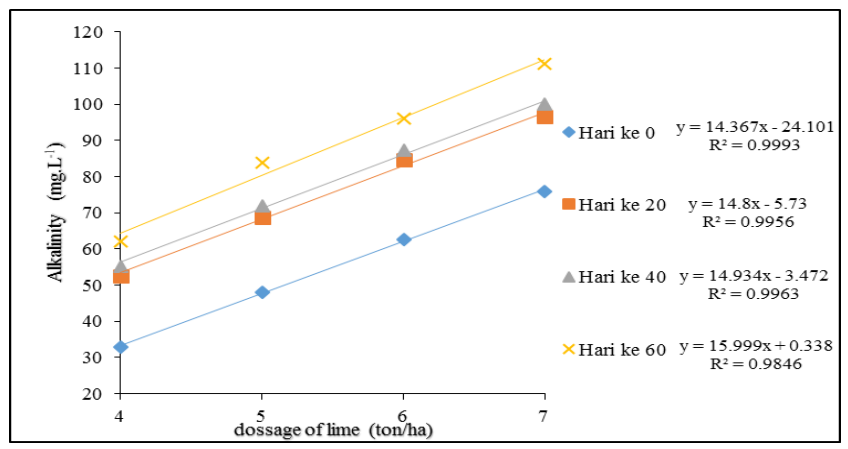


Fig. 4. Relatonship between dosage of lime and alkalinity

Table 1. Dunnet test result for Alkalinity of water

\begin{tabular}{|c|c|c|c|c|}
\hline Treatments & Day-0 & Day-20 & Day-40 & Day-60 \\
\hline P1 & $33.33^{*}$ & $52.67^{*}$ & $55.33^{*}$ & $62.00^{*}$ \\
\hline P2 & $48.00^{\text {tn }}$ & $68.67^{*}$ & $72.00^{*}$ & $84.00^{*}$ \\
\hline P3 & $62.67^{*}$ & $84.67^{\text {tn }}$ & $87.33^{\text {tn }}$ & $96.00^{\text {tn }}$ \\
\hline P4 & $76.00^{*}$ & $96.67^{*}$ & $100.00^{*}$ & $111.33^{*}$ \\
\hline P5 & 52.00 & 80.00 & 82.00 & 92.00 \\
\hline
\end{tabular}

*) : significant difference with control (P5), tn : unsignificant difference with control (P5)

The water temperature and dissolved oxygen (DO) of ponds (Table 2) ranged from 27.8 to $32.1{ }^{0} \mathrm{C}$ and from 4.7 to $6.0 \mathrm{mg} \mathrm{L}^{-1}$, respectively. All treatment showed that the ammonia concentration increased in the final day of research (day $60^{\text {th }}$ of culture) (Figure. 5). The water temperature and dissolved oxygen of the ponds remained within the appropriate range for normal growth of juvenile Pangasius sp [7] ranging from $27^{\circ} \mathrm{C}$ up to $30^{\circ} \mathrm{C}$ for temperature and $>5 \mathrm{mg} \mathrm{L}^{-1}$ for dissolved Oxygen. No significant effect of lime application on dissolved oxygen at the end of rearing period was detected. Some data of temperatures the optimal value, and there were some of data DO less than optimum range but still in tolerance range for Pangasius sp. culture.

Table 2. Dissolved Oxygen range and Temperature

\begin{tabular}{|c|c|c|c|c|c|}
\hline \multirow{2}{*}{ Variables } & \multicolumn{5}{|c|}{ Treatments } \\
\cline { 2 - 6 } & P1 & P2 & P3 & P4 & P5 \\
\hline Temperature $\left({ }^{\circ} \mathrm{C}\right)$ & $27.8-32.1$ & $28.2-31.9$ & $28.2-31.8$ & $28.0-31.9$ & $28.0-31.9$ \\
\hline Dissolved Oxygen $\left(\mathrm{mgL}^{-1}\right)$ & $5.1-5.8$ & $4.8-5.9$ & $4.8-6.0$ & $4.7-5.8$ & $4.9-5.9$ \\
\hline
\end{tabular}

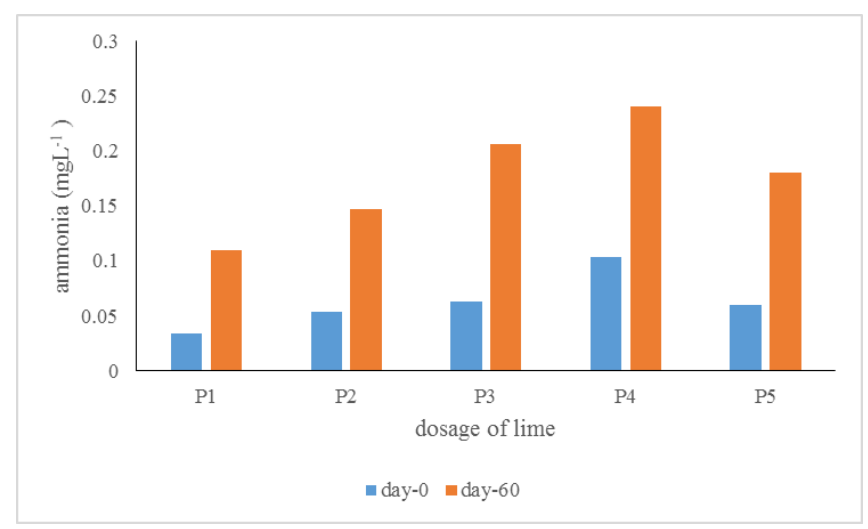

Fig. 5. Ammonia concentration in the initial (day 0 of culture) and final (day 60 of culture)

Table 3. survival, growth and feed efficiency of catfish

\begin{tabular}{|c|c|c|c|c|c|}
\hline \multirow{2}{*}{ Variable } & \multicolumn{5}{|c|}{ Treatments } \\
\cline { 2 - 6 } & P1 & P2 & P3 & P4 & P5 \\
\hline Survival (\%) & 100 & 100 & 100 & 100 & 100 \\
\hline Absolute growth of weight (g) & $30.09^{*}$ & $33.53^{*}$ & $37.44^{\text {tn }}$ & $40.56^{*}$ & 37.62 \\
\hline Absolute growth of length (cm) & $11.71^{*}$ & $12.56^{*}$ & $13.35^{\text {th }}$ & $15.39^{*}$ & 13.57 \\
\hline Feed eficiency (\%) & $88.67^{*}$ & $91.33^{*}$ & $95.03^{\text {th }}$ & $100.42^{*}$ & 95.11 \\
\hline
\end{tabular}

$*)$ : significant difference with control (P5), tn : unsignificant difference with control (P5) 
The survival rate for all treatments was $100 \%$. The highest absolute growth and feed efficiency was achieved on P4 ( lime derived from $P$. canaliculata 7 ton/ha equivalent to $\mathrm{CaO}$. The absolute growth (both weight and length), and feed efficiency were significantly affected by dosage of lime appication ( $>>0.05$ ) (Table 3 ). The high survival rate indicates that the water $\mathrm{pH}$ is within the tolerant or optimal values of $\mathrm{pH}$ for Pangasius sp. Growth. Based on Dunnett test showed that lime derived form $P$. canaliculata dosage 7 ton/ha was unsignificant different with calcite dosage 6 ton/ha. Meanwhile, below that dosage still have lower growth and feed eficiency than calcite 6 ton/ha (P5).

\section{Conclusions}

Liming materials from $P$. canaliculata shells potential to be an altenative lime for catfish swamp ponds. Maximal water's $\mathrm{pH}$ value of lime derived from $P$. canaliculata almost same as calcite (6ton/ha), but the day to reach maximum $\mathrm{pH}$ value of calcite longer than $P$. canaliculata shells. Medium with lime and calcite at same dosage ( 6 ton/ha) has no significant difference of alkalinity. Meanwhile, fish growth and feed eficiency at lime derived form $P$. canaliculata shells 7 ton has no significant difference effect to growth and feed eficiency with calcite 6 ton/ha.

\section{Acknowledgments}

We would like to thank Institute for Research and Community Services, Sriwijaya University that had funded this study through Competetive Grant 2017.

\section{References}

1. Vijayakumar, P. and R. Vasudeva. Karnataka J. Agric. Sci 24, 4 (2011)

2. Jubaedah, D., Marsi, R.R. Rizki. J. Aquacultura Indonesiana 18, 2 (2017)

3. Jubaedah, D., M.M. Kamal, I. Muchsin, and S. Hariyadi. J. Manusia dan Lingkungan 22, 1 (2015).

4. Wilkinson, S. J. Aquaculture Asia (2002)

5. APHA (American Public Health Association). 22nd Edition. American Water Works (Washington D.C, 2012)

6. Boyd, C. E., M. Boonyaratpalin and T. Thunjai. J. Aquaculture Asia 7 (2002)

7. SNI (Standar Nasional Indonesia), (Jakarta, 2000) 